\title{
Introduction to the Symposium on a Way Forward
}

\section{Academic and Practitioner Perspectives on the ILC Draft Articles on Prevention and Punishment of Crimes Against Humanity as adopted on Second Reading ${ }^{*}$}

\author{
Charles C. Jalloh \& Leila N. Sadat ${ }^{* *}$
}

\section{Introduction}

In 2013, the International Law Commission ('ILC' or 'the Commission'), an independent expert body established by the United Nations General Assembly, added the topic of 'Crimes Against Humanity' to its long-term programme of work. ${ }^{1}$ The following year the ILC moved the topic to its current programme of work and appointed a special rapporteur for the topic. ${ }^{2}$ Five years later, in 2019, the ILC completed its second reading on the topic of crimes against humanity and produced a set of 'Draft Articles'3 on the prevention and punishment of crimes against humanity. The Commission submitted its final text, with commentaries, to the UN General Assembly with a recommendation, pursuant to the provisions

* The authors are grateful to Ashira Vantrees and Madaline George for their excellent research assistance and for all their help with the preparation of this special issue. They also thank Selma Soetenhorst-Hoedt and Ingrid Knotters, both of Eleven International Publishers, for their support and flexibility which allowed for the timely publication of this special issue.

** Charles C. Jalloh is Professor of Law, Florida International University and Member and Chair of the Drafting Committee (seventieth session) and Rapporteur (seventy-first session), International Law Commission. Email: jallohc@gmail.com. Leila N. Sadat is James Carr Professor of International Criminal Law and Director, Whitney R. Harris World Law Institute, Washington University School of Law.

1 Int'l Law Comm'n, Report on the Work of Its Sixty-Fifth Session, U.N. Doc. A/68/10, at Para. 170 (2013).

2 The Commission appointed Mr. Sean Murphy (USA) as the Special Rapporteur for the topic. See Int'l Law Comm'n, Report on the Work of Its Sixty-Sixth Session, U.N. Doc. A/69/10, at Para. 266 (2014).

3 At the outset, for reasons of transparency, we wish to flag and explain our use of 'draft articles' as opposed to 'articles'. In practice, for the ILC, codification items proposed to the General Assembly upon second reading are typically styled 'draft articles'. Once the General Assembly takes action, whether welcoming or taking note of the outcome of the Commission's work, items may, from the perspective of the Sixth Committee, be typically referred to as 'articles'. In this introduction, we have opted to use the term 'draft articles'. On this issue of form, it is hard to find a single and consistent approach, given the divergent practices in referring to the outcomes of the ILC's outputs in legal academia and in the works of national and international courts and tribunals. As editors, we sought a measure of harmony, but did not ultimately require that contributing authors to this symposium use 'draft articles' or 'articles' since it was more appropriate to leave each author a measure of choice on this issue. We are grateful to Arnold Pronto, of the ILC and Sixth Committee Secretariats, for sharing his insights on this specific question. 
of its statute, that states either elaborate a convention in the UN or convene a diplomatic conference to negotiate a convention based on the draft articles. ${ }^{4}$ The Commission's work took note of scholarly efforts underscoring the importance of crimes against humanity prosecutions in international criminal law and the gap in the existing international legal framework in respect thereof. ${ }^{5}$

In the subsequent fall 2019 Sixth Committee debate, most states welcomed the ILC draft articles and endorsed one or the other of the ILC recommendations. Austria offered to host a diplomatic conference in Vienna, thereby offering a solution to one of the potential practical challenges for one of the recommendations. However, a handful of states felt either that no new convention was needed, cited concerns about the substance of the ILC project or expressed concern about the parallel initiative promoting a mutual legal assistance treaty for core crimes as reasons for caution.

Given the complexity of the project and the release of the ILC's final report, only two months earlier, several states suggested additional time was needed for consideration of the ILC's text, including the relationship of the ILC draft articles to states' national laws. They offered suggestions on a structured multistep process that could be used to evaluate the ILC draft articles with view to later taking a decision on them. In the end, the UN General Assembly adopted Resolution 74/187, on 18 December 2019, in which it could only 'take note'6 of the ILC's draft articles and decided to include the topic in the provisional agenda of its Seventy-Fifth (2020) session with a view to continuing to examine the ILC's recommendation.

The year 2020 seems potentially important for the General Assembly's decision on crimes against humanity. It also appears significant that forty-three states expressed some disappointment that the Sixth Committee was unable to agree on an 'ambitious and structured approach"7 to the deliberations on the ILC's recommendation. ${ }^{8}$ A structured approach would have provided for the views of all states to be heard, while at the same time establishing a step-by-step procedure, perhaps backed by timelines, allowing states ample time for the consideration of the substantive ILC proposal. Similar structured approaches have been used more recently by states in the context of discussions of other possible international instruments, for example, the Arms Trade Treaty ${ }^{9}$ and the international legally

4 Int'l Law Comm'n, Report on the Work of Its Seventy-First Session, U.N. Doc. A/74/10, at Para. 42 (2019).

5 See M.C. Bassiouni, 'Crimes Against Humanity: The Need for a Specialized Convention', Columbia Journal of Transnational Law, Vol. 31, 1994, pp. 457-494; L.N. Sadat (Ed.), Forging a Convention for Crimes Against Humanity, 2nd ed., Cambridge, Cambridge University Press, 2013.

6 GA Res. 74/187, 18 December 2019.

7 Statement by Austria (on behalf of 42 other countries), Seventy-fourth Session of the General Assembly, Sixth Committee, under agenda item 79 (20 November 2019).

8 L.N. Sadat \& M. George, 'An Analysis of State Reactions to the ILC's Work on Crimes Against Humanity: A Pattern of Growing Support', African Journal of International Criminal Justice, 2020 (in this volume).

9 Arms Trade Treaty, adopted by GA Res. 67/234, 2 April 2013, entered into force 24 December 2014. See United Nations, Arms Trade Treaty, available at: www.un.org/disarmament/convarms/ arms-trade-treaty/ (last visited 1 September 2020). 
binding instrument under the United Nations Convention on the Law of the Sea on the conservation and sustainable use of marine biological diversity of areas beyond national jurisdiction ('the BBNJ process'10). While the Arms Trade and BBNJ process examples were not textual outcomes of ILC work, the approach that states successfully took in those instances could well inform the General Assembly's process to find consensus on a path forward towards a multilateral global instrument on the prevention and punishment of crimes against humanity. ${ }^{11}$

\section{The AJICJ and the Goal of This Special Issue}

With the 2020 Sixth Committee debate swiftly approaching, provisionally fixed for early October 2020, the early autumn of 2020 appeared to be an opportune time for the African Journal of International Criminal Justice (AJICJ) to publish a special issue on the topic crimes against humanity. The AJICJ is a peer-reviewed journal, of which one of us is the founding editor-in-chief and the other a member of the advisory board, that serves as a forum for scholars from all regions of the world, especially the Global South, to examine timely issues of international criminal law and transitional justice from the developing world as analysed by authors drawn from those geographic regions and globally.

The AJICJ seeks to carve out an intellectual space for profound scholarly reflection on the phenomenon of atrocity crimes in Africa and around the world and national, regional as well as international efforts to combat such crimes through national criminal prosecutions, traditional justice approaches such as gacaca or other alternatives such as truth commissions, lustrations and vetting. By providing an outlet for solid scholarship, the AJICJ hopes to stimulate and contribute to an Intra-South as well as South-North and North-South dialogues on the complexities facing societies transitioning from war and other collective traumas such as pre- and post-election violence to sustainable peace and stability.

The relatively limited number of voices hailing from the Global South during discussions of international law and justice has been exacerbated by the relative inability of smaller states to expend vast resources to employ large numbers of staff at their respective UN missions. For example, although many states from various regions participated in the Sixth Committee debate on the ILC draft articles in 2019, informal conversations suggest that it may be challenging for smaller states to follow up on issues after the plenary is over. This is partly due to the extensive responsibilities and portfolios already overstretched staff, including

10 See GA Res. 72/249, 24 December 2017 (intergovernmental conference on an international legally binding instrument under the United Nations Convention on the Law of the Sea on the conservation and sustainable use of marine biological diversity of areas beyond national jurisdiction).

11 See, e.g., GA Res. 49/53, 9 December 1994 (establishing an ad hoc committee "to review the major substantive and administrative issues arising out of the draft statute [for an international criminal court] prepared by the International Law Commission and, in the light of that review, to consider arrangements for the convening of an international conference of plenipotentiaries"). 
those covering the Sixth Committee, from smaller diplomatic missions are already tasked with. ${ }^{12}$

This special issue of the AJICJ, on the ILC's recent work on crimes against humanity, fits into the above wider context. It also fits with a broader goal of also contributing to deepening global understanding and engagement in different parts of the world, especially in Africa and the developing world, with the work of the ILC as the principal international law codification body of the United Nations. Needless to say, international law, whether or not people pay attention to it or even know of it, impacts significantly on the lives of people around the world. We are thus pleased, in collaboration with the publisher, to have been able to offer a scholarly-practitioner space for additional voices - particularly from the Global South - to join the debate on this important topic and to also contribute to improving dialogue and the exchange of views between members of the ILC and the Sixth Committee as well as broader legal academia and global civil society.

As the AJICJ plans to host more special symposiums on ILC topics in the future, including their intersections with the work of regional codification bodies that are frequent visitors of the Commission in Geneva such as the African Union Commission on International Law, the Asian-African Legal Consultative Organization and the Inter-American Juridical Committee, this special issue on crimes against humanity is set to be only the first of a series that we hope will contribute to enriching global debates on pressing questions of concern for the Global South and the international community as a whole.

\section{A Brief Overview of the ILC Topic Selection Process}

In this issue many of the articles discuss the history of the topic of crimes against humanity at the ILC; therefore, it seems beneficial to provide a brief overview of the ILC process for readers to keep in mind as they review these contributions. When the ILC was founded in 1947 its mandate was to promote the codification and progressive development of international law. ${ }^{13}$ That remains the case today. The Commission aims to do this by addressing areas of mostly public international law by topic though its formal mandate also explicitly covers private international law.

Over the ILC's life span, the Commission has considered around fifty-seven topics and appointed about sixty-one special rapporteurs and along the way made substantial contributions to the development of modern international law. ${ }^{14}$ The General Assembly, principal organs and specialized agencies of the United

12 M.I. Kanu, '70 Years of the International Law Commission, Its Future Role in the Changing Landscape of International Law and the Small-Developing States Nexus', FIU Law Review, Vol. 13, No. 6, 2019, pp. 1043-1064.

13 GA Res. 174 (II), 21 November 1947.

14 Int'l Law Comm'n, Research Periods During Which Topics Were on the Agenda of the International Law Commission, available at: https://legal.un.org/ilc/guide/annex1.shtml (last visited 1 September 2020); Int'l Law Comm'n, Membership: Special Rapporteurs of the International Law Commission (1949-2016), available at: https://legal.un.org/ilc/guide/annex3.shtml (last visited 1 September 2020). 
Nations may refer proposals for the progressive development of international law of interest to the ILC. ${ }^{15}$ As regards codification, states also entrusted the Commission with the responsibility of surveying the whole field of international law to select appropriate topics and recommend those topics to the General Assembly for codification. ${ }^{16}$ In determining which topics to take up on its own initiative, the ILC is guided by its internal two-step procedures, solidified in the mid-1990s, that require a topic first to be added to the Commission's long-term programme of work and then to its current programme of work.

Initially, for a topic to be added to the long-term programme of work a member of the Commission or the ILC Secretariat may present a proposal on a given topic that includes (1) the major issues raised by the topic; (2) any applicable treaties, general principles or relevant national legislation or judicial decisions; (3) existing doctrine; and (4) the advantages and disadvantages of taking up the topic and the form it should assume. ${ }^{17}$ The explanatory proposal is then presented to the ILC's Working Group on the Long-Term Programme of Work. This Working Group, which is open to any member that volunteers to serve on it and is typically composed in the first year of the quinquennium, considers the proposals of individual members and determines which, if any, topics will be recommended to the Planning Group and thereafter the Plenary of the Commission for possible addition to the Commission's long-term programme of work. All decisions on topics, at all the levels, are taken by consensus - which often means unanimous or broad support or even the absence of strong objections.

In selecting topics for inclusion on the long-term programme of work, the Commission is guided by the criteria established during its forty-ninth session (1996), which requires that the proposed topic (1) reflect the needs of states in respect of the progressive development and codification of international law; (2) be sufficiently advanced in stage in terms of state practice to permit progressive development and codification; (3) is concrete and feasible for progressive development and codification and (4) that the Commission shall not restrict itself to traditional topics but also topics reflecting newer developments in international law and pressing issues of concern to the international community as a whole. ${ }^{18}$ With these criteria in mind, the Working Group on the Long-Term Programme of Work then discusses and debates, usually in formal private meetings, the various topic proposals. The chair of the Working Group on the Long-Term Programme of Work, currently Mr. Mahmoud Hmoud, presents an oral report to the Planning

15 Statute of the International Law Commission, GA Res. 174 (II), 21 November 1947, as amended by GA Res 485 (V), 12 December 1950, GA Res. 984 (X), 3 December 1955, GA Res. 985 (X), 3 December 1955, and GA Res. 36/39, 18 November 1981, Art. 16.

16 Ibid., Art. 18.

17 Int'l Law Comm'n, About the Commission, available at: https://legal.un.org/ilc/programme.shtml (last visited 3 August 2020).

18 Int'l Law Comm'n, Report on the Work of Its Forty-Ninth Session, U.N. Doc. A/52/10 (1997), at Para. 238. 
Group which in turn reports to the Commission stating which topics found support and are being recommended for the long-term programme of work. ${ }^{19}$

From there, assuming consensus is found in the plenary, the Commission includes a syllabus for each topic that is added to the long-term programme and annexed to its annual report. ${ }^{20}$ In the annual report submitted to the Sixth Committee, typically in the last chapter addressing other decisions, states are invited to comment on the addition of the topic to the long-term programme of work. The feedback given by states, on the suitability of the topic, is seen as vital to the Commission's separate and subsequent decision on the topic.

Depending on a range of factors, especially the availability of space and a potential special rapporteur, the year after the topic is added to the long-term programme of work or at a later stage, the Commission reviews the responses received and examines the potential transfer of the topic from the long-term programme of work to the current programme of work and the appointment of a special rapporteur to the topic. Whereas the decision to add a topic to the longterm work programme is ultimately taken by the Commission as a whole, the decision to move a topic to the current programme of work is taken by the Bureau of the Commission comprised of the five officers nominated to represent each of the five regions, for each session, following consultations of the wider membership on a regional basis. States, especially the African Group, have taken note, for example during the Sixth Committee debate in October 2019, that certain regions of the world such as Africa, Asia and Latin America have been under-represented in the number of special rapporteurs, calling for the ILC to take a more balanced approach both in terms of the topics it selects as well as the special rapporteurs as this would help enhance the representativeness of the principal legal systems of the world in the work of the Commission as well as to enhance the legitimacy of its work.

19 The following ten topics are, as of writing in September 2020, on the ILC's long-term programme of work: ownership and protection of wrecks beyond the limits of national maritime jurisdiction (see Addendum 2 of the 1996 ILC Report to the General Assembly); jurisdictional immunity of international organizations (Ann. II); protection of personal data in transborder flow of information (Ann. IV); extraterritorial jurisdiction (Ann. V); the fair and equitable treatment standard in international investment law (Ann. IV); the settlement of international disputes to which international organizations are parties; evidence before international courts and tribunals (Ann. B); universal criminal jurisdiction; reparation to individuals for gross violations of international human rights law and serious violations of international humanitarian law; and prevention and repression of piracy and armed robbery at sea.

20 C.C. Jalloh, 'Introduction: The Role and Contributions of the International Law Commission to the Development of International Law, a Symposium Celebrating the 70th Anniversary of the ILC', FIU Law Review, Vol. 13, No. 6, 2019, pp. 975-987; C.C. Jalloh, 'The International Law Commission's First Draft Convention on Crimes against Humanity', African Journal of International Criminal Justice, No. 2, 2019, pp. 119-167. 


\section{The Addition of Crimes Against Humanity to the ILC's Programme of Work}

For the topic of crimes against humanity, the foregoing process began in 2013 when the Working Group on the Long-Term Programme of work recommended that the topic be added to the Commission's long-term programme of work. ${ }^{21} \mathrm{In}$ 2014 , following a conference ${ }^{22}$ that involved academics and members of the Commission in Geneva, the topic 'crimes against humanity' was moved to the Commission's current programme of work. Consistent with the tradition of the ILC, the topic's proponent, Mr. Sean Murphy, was appointed Special Rapporteur for the project.

Each year thereafter, with the exception of 2018, when the topic was in abeyance for first reading comments from states and other observers, two debates took place on the crimes against humanity topic. The first would be in the Commission in the summer and the second in the Sixth Committee of the General Assembly in the autumn. Importantly, in each annual debate, states provided feedback on the individual draft articles and commentary adopted by the Commission each year. The comments would be reviewed by the special rapporteur and reflected in his next report.

Because the Commission members review both the new special rapporteur report and the verbatim and summary records of the debate, along with the topical summary of the Sixth Committee Secretariat, which also doubles as the Secretariat for the ILC, the sense of the direction that the participating states preferred to see becomes clearer to the Commission members. The views of states would then naturally be taken into account in the ILC debates both in the plenary debate and in the drafting committee. Hopefully, a geographically representative group of states will comment, to give the valuable guidance that the Commission requires. This ongoing ILC-Sixth Committee dialogue on topics means that there are hardly any surprises for states in the content and direction of ILC topics.

Within three years of the topic's addition to the Commission's current programme of work, and building on the familiar work of well-established treaties addressing the crime of genocide, torture, enforced disappearance, corruption, transnational organized crime and other multilateral instruments in the field of transnational criminal law, the Commission successfully produced an entire set of draft articles with commentaries for states to review on first reading. ${ }^{23}$

The first reading is a crucial time in the life of a topic in the Commission. It allows states to review the entire package of proposals from the ILC accompanied by commentaries. At this stage, the text reflects both majority and minority opinions within the Commission, and the reasons therefor. In the course of

21 Int'l Law Comm'n, Report on the Work of Its Sixty-Fifth Session, supra note 1, at Ann. B.

22 L.N. Sadat \& D.J. Pivnichny, 'Fulfilling the Dictates of Public Conscience: Moving Forward with a Convention on Crimes Against Humanity', Whitney R. Harris World Law Institute, 17 July 2014, available at: http://sites.law.wustl.edu/docs/harris/Final-CAHGenevaReport-071714.pdf.

23 Int'l Law Comm'n, Crimes against humanity texts and titles of the draft preamble, the draft articles and the draft annex provisionally adopted by the drafting committee on first reading, U.N. Doc. A/CN.4/L.892/Add.1 (2017). 
reviewing the Commission's annual report, states have the opportunity to comment during the annual debate within the Sixth Committee and may also, additionally, submit written comments on the Commission's work. The deadline for the latter is usually the end of the year, whereas the Sixth Committee debate is limited to a two-week duration, with a limited amount of time for a variety of topics to be discussed, only one of which is the Report of the International Law Commission.

For crimes against humanity, consistent with this settled practice, the first reading stage of the topic thus provided an opportunity for the states to consult different national departments and formulate their positions on the text. Their written submissions on first reading text, which gives a longer time frame for consultations to occur in capitals and in different ministries and with academia and civil society, then give the Commission a deeper idea of the variety of positions taken by states and their views on how the ILC should, from their own vantage points, complete its work.

Of course, this formalized exchange of views increases the transparency of the Commission's work and helps to ensure that the work of the ILC accurately reflects established state practice and current international law. However, on all topics, there is a delicate balance that must be struck by the Commission and its members. This is because, while all members carefully review the comments of states and take them on board in the course of the work even as they reflect on the state of current law, the Commission - by the express wish of the General Assembly itself - is intended to be a body of independent experts serving in their individual capacities as persons of recognized competence in international law. States, when the ILC was being founded, had even been presented an option of staffing the Commission with representatives of governments. They declined that recommendation in a critical decision that has proved to serve the General Assembly and the field of international law well. Therefore, although state comments may be instructive in framing the Commission's final work, they are not necessarily dispositive.

The independence of the Commission is, in many respects, born of practical necessity and is well established and familiar to states in the course of the sevendecade long history of the ILC. Given that 193 states have the opportunity to comment on any given topic (and in fact, about 155 states commented on the ILC's work on crimes against humanity from the floor of the Sixth Committee), ${ }^{24}$ as well as the large variety in state views, it would be impossible for the Commission to modify its proposals to accommodate every comment, particularly if comments pull in opposite directions. Thus, the members of the ILC are expected to use their expertise to adopt solutions that seem most consistent with the mandate of the Commission to assist the General Assembly with the promotion of the codification and progressive development of international law. ${ }^{25}$ The other side

Statute of the International Law Commission, supra note 15, Art. 1(1) ("The International Law Commission shall have for its object the promotion of the progressive development of international law and its codification"). 
of this, of course, is that it is the General Assembly itself that gets to have the last word. There, states ultimately decide what to make of the Commission's substantive recommendations, whether in relation to the detailed text of its projects or in relation to the ultimate outcome of the ILC's final drafts and, if those are draft articles, whether to negotiate a treaty on the basis of the ILC drafts and to thereafter join and implement the relevant treaty in their national laws.

On the first reading of the crimes against humanity draft articles, it is notable that there was a wide variety of state participation in the discussion. ${ }^{26}$ In fact, while we have not examined the issue in the context of the full seventy years of the Commission, the number of written comments from states and other observers on the crimes against humanity was the highest number of comments received on an ILC topic in at least the past two decades. ${ }^{27}$ During the Sixth Committee's debate on the draft articles, states proved to be highly supportive of the project. Many commended the Commission for its work, noting that it would help advance on the horizontal level the achievement of some of the core goals contained in the Rome Statute of the International Criminal Court. ${ }^{28}$

Further, nearly forty states supported the idea of taking the ILC draft articles forward to a diplomatic convention with a view to negotiating a treaty. ${ }^{29}$ Two years later, on second reading, after the ILC had announced its completion of the project, states remained receptive and, in some cases, enthusiastic towards the idea of turning the draft articles into a binding conventional instrument. Despite the sustained enthusiasm, during the Sixth Committee debate, it appears that consensus could not yet be reached on whether to convene a diplomatic conference or to negotiate the draft articles in New York. ${ }^{30}$ Time was simply too short to find agreement. In an encouraging sign of the close cooperation and complementarity between the Sixth Committee and the ILC, however, the UN General Assembly did establish in its resolution that the conversation on the ILC recommendation would continue during the Seventy-Fifth General Assembly (2020). ${ }^{31}$ This decision is welcome, considering the present uncertainty concerning several of the more recent outcomes of the Commission's work, a matter of increasing concern to the ILC and its members and states reliant on international law in view of its potential negative implications.

26 For a summary, see S. Murphy (Special Rapporteur on Crimes against Humanity), Fourth Report on Crimes Against Humanity, Para. 15 U.N. Doc. A/CN.4/725, 18 February 2019. For the ILC Secretariat compilation of the comments received from states and other observers, see 'Crimes against humanity: Comments and observations received from Governments, international organizations and others', U.N. Doc. A/CN.4/726; U.N. Doc. A/CN.4/726/Add.1; U.N. Doc. A/ CN.4/726/Add.2.

27 The individual government comments received between 2015 and 2019 on the crimes against humanity topic are available under the analytic guide, available at: https://legal.un.org/ilc/guide/ 7_7.shtml\#govcoms (last visited 1 September 2020).

28 Murphy, supra note 26, at Paras. 20-21.

29 Ibid., at Para. 22.

30 GA Res. 74/187, 18 December 2019.

31 Ibid. 


\section{An Overview of the Articles in This Special Issue}

Turning now to the substance of this special issue. The issue opens with a short Foreword from the ILC's Special Rapporteur on Crimes against Humanity, Sean Murphy. Although his contribution to this volume is brief, his larger role concerning the project it analyses has been substantial. Murphy's contribution, from working with colleagues on the Commission to frame the topic, to moving it to the Commission's active agenda and to completing the work in excellent time, has advanced the goal of elaborating and potentially adopting a new global treaty on crimes against humanity considerably. Yet, as he notes, there may still be provisions in the ILC draft articles that might well be deleted or modified, and elements, such as the possible establishment of a Treaty Monitoring Body, that should be added. Moreover, as he suggests, one of the key questions still remaining is whether a convention is politically feasible and whether states would negotiate, adopt, ratify and, perhaps most crucially, implement it. Those questions and more are taken up in the excellent contributions that follow.

Conceptually, the issue may be divided into three categories. The first group of articles examine the Commission's project from various regional perspectives, as well as situating regional responses within the discussions of the draft articles in the Sixth Committee. We begin with The ILC Draft Articles on Crimes Against Humanity: An African Perspective by Alhagi B.M. Marong. Marong's article provides a much needed analysis of the ILC's draft articles from an African perspective while addressing the history of post-colonial atrocity crimes in Africa and how the experience of African states should encourage them to support the creation of a treaty on the prohibition of crimes against humanity at the horizontal level. While he expressed concern about the relatively low level of participation of African states in offering comments on the draft articles, during the drafting process, he notes that it was an African jurist - the late M. Cherif Bassiouni from Egypt - who, in a sense, laid much of the foundation on which the proposed draft articles were built. Moreover, in their capacity as independent experts, he shows that some African members of the Commission were quite active in their engagement on the text. These members influenced the text in the context of the give and take that is an inherent part of the ILC's collegial work as a multilateral global body anchored in the United Nations. In any event, we can observe that the next stage of the process, should states, including the African Group, agree to move forward with a convention, potentially gives African and other states an equal opportunity to advance their vision of a treaty on global crimes against humanity - as they have done in other contexts such as the negotiations of the Rome Statute of the International Criminal Court in 1998.

Second, Sergey Sayapin presents Why a Crimes against Humanity Convention from a Perspective of Post-Soviet States? This article expands on the history of international criminal law and makes a compelling argument as to why postSoviet states, a majority of which have accepted the Rome Statute, have already adopted legislation on crimes against humanity at the national level and should therefore be future parties to crimes against humanity treaty. He notes that the treaty touches on certain sensitivities in the region but that a future diplomatic 
conference would represent an occasion to address any concerns, in order to render the convention acceptable to as many states as possible.

Third, Beth Van Schaak's article Crimes Against Humanity in the 'Western European and Other' Group of States: A Continuing Tradition notes that the Western Europe and Other Group (WEOG) states have a long history with the push to develop the prohibitions of crimes against humanity. She traces the commission of these crimes in the West and observes that this led to the pivotal role that Western nations have played in their creation as a category of crimes under international law, in launching prosecutions in both international and national courts, and in formulating the modern definition of the crime. Thus, she argues that it would be beneficial for WEOG states to embrace the ILC's draft articles on the proposed Crimes Against Humanity Convention and help lead the call for a convention on the prohibition of crimes against humanity.

Fourth, coming from Asia, Mari Takeuchi's article, Asian Perspectives on the International Law Commission's Work on Crimes Against Humanity, provides an analysis of the comments of Asian states, or rather the lack of comments, during the Sixth Committee debate. She notes that no Asian State expressed regret that no crimes against humanity treaty emerged from the Sixth Committee last autumn, and that most states from this region that commented suggested that further discussions were needed before moving on to the next stage. She situates this in the wider context, however, noting that although Asian states have approached international criminal law cautiously with relatively low ratification rates of existing treaties in this field, this does not mean that they are indifferent to concerns about atrocities and the development of international criminal law. Takeuchi notes the increasing engagement of Asian states with the field, while, at the same time, maintaining a certain distance from the regime anchored by the International Criminal Court.

Fifth, Leila Sadat and Madaline George's article, An Analysis of State Reactions to the ILC's Work on Crimes Against Humanity: A Pattern of Growing Support analyses the position of states on crimes against humanity even prior to the ILC taking up the topic, categorizing the response of each state as either strongly positive, positive, neutral, negative or strongly negative. The article empirically demonstrates increasing support over time for the ILC project, despite the initial concern that any future treaty on crimes against humanity does not interfere with or conflict with the Rome Statute and the International Criminal Court.

Sixth, Hugo Relva's A Civil Society Perspective on the ILC Draft Convention on Crimes Against Humanity provides a compelling argument not only for why states should take up and negotiate a crimes against humanity treaty but also for why they should go further than the ILC's draft articles and ensure that states are not signing a treaty that represents a bare-minimum convention when the standards for international law can be much higher.

A second cluster of articles in this volume examine specific provisions of the draft articles against the wider background of international criminal law, as well as in view of state comments on the Draft Articles. The first of these, Margaret $M$. deGuzman's article Defining Crimes Against Humanity: Practicality and Value Balancing, offers insights on the development of the definition of crimes against 
humanity in the Rome Statute, which also served as the basis for the ILC draft articles. She notes how the crime has evolved in terms of the concept of gravity and its elements, as well as overwhelming concerns expressed by states regarding the Rome Statute's definition of gender.

Picking up from where deGuzman leaves off, Indira Rosenthal and Valerie Oosterveld's article Gender and the ILC's 2019 Draft Articles on the Prevention and Punishment of Crimes Against Humanity discusses the evolution of gender-based crimes in international law and the ambiguity of the term 'sexual violence.' They observe that the elaboration of a treaty on crimes against humanity provides a critical opportunity to affirm that gender-based crimes are among the gravest crimes under international law. They also consider a number of concerns raised by states and civil society regarding the definition of some of the gender-based crimes included in the draft articles and recommend that a comprehensive gender analysis of all the draft articles be carried out.

The third article is authored by Claudio Grossman, a member of the International Law Commission. His article, ILC Report on Prevention and Punishment of Crimes Against Humanity and Enforced Disappearance, provides an insightful comparison on the approach used in defining enforced disappearance as a crime against humanity at Rome and makes the case for a broader acceptance in a subsequent international instrument that could potentially be used to define crimes against humanity in a more encompassing way while allowing it to secure more effectiveness in pursuing enforced disappearance as a crime against humanity. Grossman also takes issue with aspects of the 'without prejudice' clause in the draft articles, suggesting how it might be improved upon in future negotiations.

Fourth, Joseph Rikhof, in The International Law Commission's Draft Articles on the Prevention and Punishment of Crimes Against Humanity: Incitement/Conspiracy as Missing Modes of Liability, critiques the decision of the ILC to exclude inchoate crimes such as conspiracy and incitement and further urges for the final crimes against humanity treaty to include these modes of liability. Rikhof's contribution presents a conceptual analysis of why inclusion of these inchoate crimes would have assisted with the policy goals of preventing crimes against humanity.

The final contribution on specific aspects of the draft articles is George Mugwanya's comprehensive article, entitled Interstate Cooperation and Why a Horizontal Treaty would Make a Difference for ICC Investigations. Mugwanya explores the detailed provisions of the ILC draft articles on interstate cooperation and compares them with parallel provisions in the ICC Statute. This analysis leads him to conclude that the ILC's interstate cooperation regime, while formally operating on a horizontal, interstate level, can also fill important gaps within the International Criminal Court system. He concludes with some suggestions on improving the draft articles and strengthening the cooperation regime they provide.

In an important third part of the special issue, because it seeks to identify a way forward, taking into account the existence of a different but interrelated topic, the first contribution, by Larissa van den Herik, entitled Relating to 'The Other: The ILC Draft Convention on Crimes Against Humanity and the Mutual Legal Assistance Initiative', steps back to provide a wider comparative analysis of the ILC's work on crimes against humanity and the Mutual Legal Assistance Initia- 
tive. This separate initiative, which has the support of a number of governments, proposes to address aspects of cooperation for the core international crimes, including crimes against humanity. She notes that although the projects have proven to have overlap in some respects, each instrument has merits that the other lacks and suggests that the optimal solution would be to bring both projects to fruition.

Then, two Sixth Committee experts who were keenly following the issue last year, share important insights from their participation in the negotiation and discussions of the ILC draft articles in the General Assembly. Michael Imran Kanu's contribution, Unlocking the Sixth Committee's Potential to Act for Crimes Against Humanity as it Did for Genocide, examines the topic and the wide range of views expressed by states. Analogizing the role of the Sixth Committee, which played a vital role in the adoption of the analogous 1948 Convention on the Prevention and Punishment of the Crime of Genocide, Kanu outlines a path to 'unlock' the Sixth Committee's potential to act by proposing a separation of the organizational and substantive matters and future-proofing the further consideration of elaborating a convention through the adoption of a structured approach.

Pablo Arrocha Olabuenaga's piece, Time to Deliver: Defining a Process Towards the Negotiation of a Convention on the Prevention and Punishment of Crimes Against Humanity, addresses both the views of the Group of Latin American and Caribbean Countries (GRULAC) states and, significantly, the negotiating process more generally. Olabuenaga was an active participant in discussions, and his article sheds light on a potentially viable way forward for the ILC draft articles. As he notes, the Sixth Committee now has a unique opportunity to define the intergovernmental negotiating process. This could both close a critical gap in international criminal law and generate a new and reinvigorated dynamic between the Sixth Committee and the ILC on codification.

It is remarkable that, although writing separately and in their personal capacities, both Kanu and Olabuenaga reached essentially the two same conclusions. First, in providing substantial context and explaining the outcome of the discussions in the General Assembly in December 2019 on the crimes against humanity topic, they observe the need to distinguish between the process and the substance. Second, they both note that while it is natural for states to have differences of views on difficult technical issues, the working methods of the Sixth Committee - especially the challenge of finding consensus - may sometimes limit its ability to take broadly supported decisions. From an institutional perspective, well beyond the crimes against humanity topic, they flag a potentially important problematique for further engagement not only by the ILC and the Sixth Committee, but also by other international legal scholars, about the implications for the present status and possible future directions for the codification and progressive development of international law - undoubtedly one of the major stabilizing factors of the post-World War II international legal order.

Lastly, for the convenience of the reader, we have included in the annex the text of the draft articles on prevention and punishment of crimes against humanity as adopted by the ILC at its seventy-first session and presented to the General Assembly in its 2019 report. 
In closing, the fifteen excellent contributions in this volume span the globe as well as many aspects of the elements in the draft articles. They suggest a way forward to overcome some of the political challenges the draft articles face in moving from a project of the Commission to a treaty negotiated and adopted by states. They also take up many interesting technical questions still posed by the draft articles that may inform states' views as the project moves forward. Overall, in presenting these excellent articles on the second reading of the ILC draft articles on the prevention and punishment of crimes against humanity, it is our sincere hope that the deep array of expertise that we have assembled to analyse the outcome of the Commission's work will offer a useful addition to the literature. We are confident that the insights shared here will be useful to states in their decision-making process during the next consideration of the crimes against humanity draft articles currently scheduled for October 2020 as well as by academics and others. 